\title{
Kissing carotid arteries: an unusual cause of prevertebral swelling
}

\author{
Nazleen Soraya Muhammad Gowdh, ${ }^{1}$ Fraser Jonathan Gill, ${ }^{2}$ Luke Andrew Regan, ${ }^{3}$ \\ Struan W A Wilkie ${ }^{1}$
}

1 Department of Radiology, Aberdeen Royal Infirmary, Aberdeen, UK

${ }^{2}$ Emergency Department, Aberdeen Royal Infirmary, Aberdeen, UK

${ }^{3}$ Department of Emergency Medicine, Raigmore Hospital, Inverness, UK

\section{Correspondence to}

Dr Nazleen Soraya Muhammad Gowdh,

n.muhammadgowdh@nhs.net

Accepted 8 September 2014

CrossMark

\section{To cite: Muhammad} Gowdh NS, Gill FJ, Regan LA, et al. BMJ Case Rep Published online:

[please include Day Month Year] doi:10.1136/bcr-2014 206099

\section{DESCRIPTION}

An 80-year-old woman with a history of recurrent falls presented to the emergency department following a fall. On examination she was found to be tender at the $\mathrm{C} 4 / 5$ level. A cervical spine radiograph revealed no fractures, however, there was significant prevertebral soft tissue swelling which measured up to $3 \mathrm{~cm}$ (figure 1A). An occult fracture was suspected and a CT of the cervical spine was requested. No fracture was identified; however, there was an unexpected finding of an aberrant course of the internal carotid arteries which accounted for the prevertebral soft tissue thickening (figure 1B). The internal carotid arteries were found to be tortuous, medially displaced and almost met in the midline, a variant colloquially known as 'kissing carotids' (figure 2). Anatomical variations of the extracranial internal carotid arteries occur in approximately $5 \%$ of the general population ${ }^{1}$ and are a cause of non-traumatic prevertebral soft tissue thickening.

in midline. Prevertebral soft tissue (white arrows) but visible prevertebral fat (black arrows).
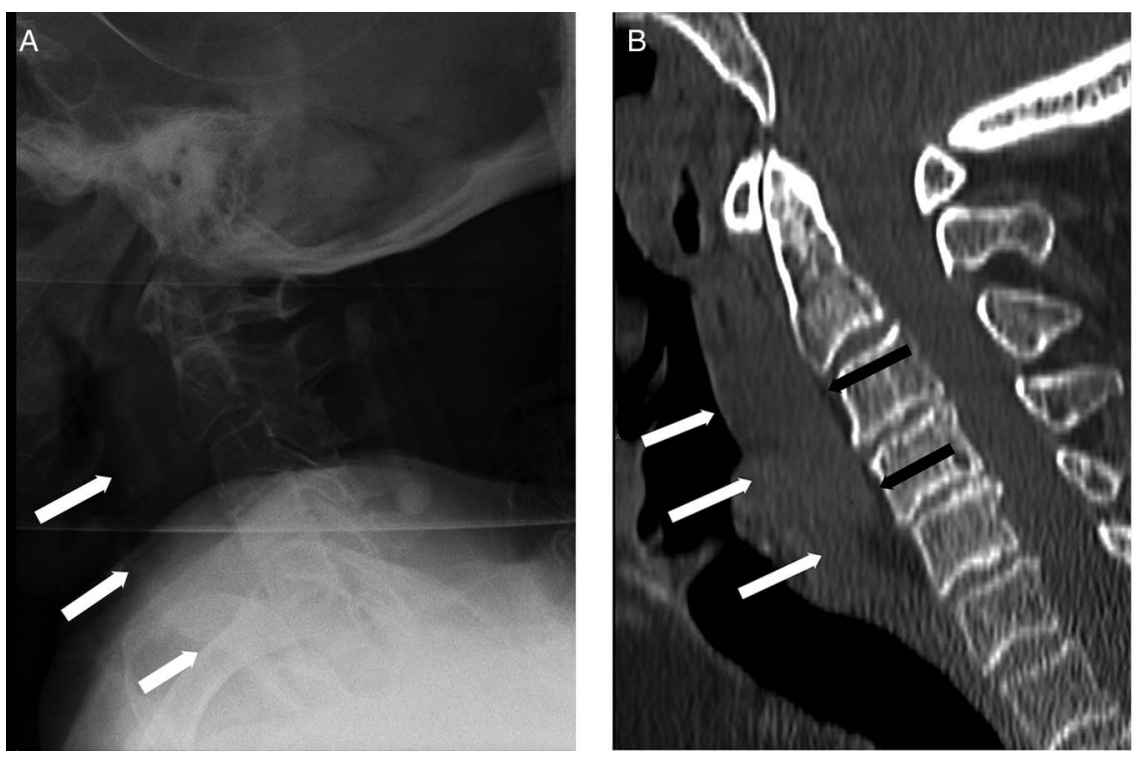

Figure 1 (A) Lateral cervical spine radiograph. Prevertebral soft tissue swelling (white arrows). (B) CT, sagittal plane

Figure $2 \mathrm{CT}$, axial plane at level of C4. Internal carotid arteries (white arrows), jugular veins (black arrows). 


\section{Learning points}

- In the trauma setting, the presence of prevertebral soft tissue swelling on a lateral cervical spine radiograph is a marker of occult vertebral fracture.

- The presence of prevertebral soft tissue thickening without a visible fracture should prompt a CT of the cervical spine.

- 'Kissing carotids arteries' are a non-traumatic cause of prevertebral soft tissue swelling which can mimic acute fracture in this setting. supervisor. NSMG continued the literature search, reviewed the literature, produced the write-up, prepared the images used in the write-up with SWAW and submitted the manuscript. LAR conducted the initial literature search together with FJG, designed the structure for the write-up, reviewed and edited the final write-up. SWAW provided the interpretation of images, prepared the images used in the write-up, reviewed and edited the final write-up.

Competing interests None.

Patient consent Obtained.

Provenance and peer review Not commissioned; externally peer reviewed.

\section{REFERENCE}

1 Pfeiffer J, Ridder G. A clinical classification system for aberrant internal carotid arteries. Laryngoscope 2008;118:1931-6.

Contributors FJG planned the study, obtained written consent, conducted the initial literature search, reviewed and edited the write-up and served as the overall

Copyright 2014 BMJ Publishing Group. All rights reserved. For permission to reuse any of this content visit http://group.bmj.com/group/rights-licensing/permissions.

BMJ Case Report Fellows may re-use this article for personal use and teaching without any further permission.

Become a Fellow of BMJ Case Reports today and you can:

- Submit as many cases as you like

- Enjoy fast sympathetic peer review and rapid publication of accepted articles

- Access all the published articles

- Re-use any of the published material for personal use and teaching without further permission

For information on Institutional Fellowships contact consortiasales@bmjgroup.com

Visit casereports.bmj.com for more articles like this and to become a Fellow 